\title{
Social Sciences
}

2015; 4(6): 127-133

Published online October 31, 2015 (http://www.sciencepublishinggroup.com/j/ss)

doi: $10.11648 /$ j.ss.20150406.11

\section{Social Inclusion of the Poor Migrants in the Contemporary Vietnamese Urban Life: A Quantitative Analysis}

\author{
Kham Van Tran', Quyet Van Pham² \\ ${ }^{1}$ Editorial Office, University of Social Sciences and Humanities, Vietnam National University-Hanoi, Hanoi, Vietnam \\ ${ }^{2}$ Graduate Office, University of Social Sciences and Humanities, Vietnam National University-Hanoi, Hanoi, Vietnam
}

Email address:

khamtv@ussh.edu.vn (K. V. Tran),p.quyet3@gmail.com(Q. V. Pham)

To cite this article:

Kham Van Tran, Quyet Van Pham. Social Inclusion of the Poor Migrants in the Contemporary Vietnamese Urban Life: A Quantitative Analysis. Social Sciences. Vol. 4, No. 6, 2015, pp. 127-133. doi: 10.11648/j.ss.20150406.11

\begin{abstract}
Vietnam is on the rapid urbanization process and wide employment changes nationwide which leads to the impacts to the inter-regional migrations, especially the rural-urban flows. Recent research and papers on social policy and current trends on migration also found that the migration makes social changes and problems in the urban life and for the migrants as well. This paper aims at identifying the inclusive process of migrants in the contemporary urban life through their daily experiences, in both living and working settings. The experience of migrants is being observed in Hanoi and Ho Chi Minh City. The initial findings expose that the inclusive trend by migrants in Ho Chi Minh City seems more positive than that in Hanoi on both sides of the migrants and the social contexts. However, in the two big cities, there is still alack of specific inclusive supports for the migrants.
\end{abstract}

Keywords: Migrant, Social Inclusion, Poor Labor, Urbanization

\section{Introduction}

Urbanisation and industrialisation has been happened with dramatic changes widely in Vietnam in last three decades which caused the flow of migration in Vietnam nationwide. Basing in the Census in 2009, there was around 7 millionsof domestic migrants in the period of 2004 to 2009 , increased by $50 \%$ in compared to the same period of 1994 to 1999 . Clearly that the migrants, in any forms, is being increased year by year and it is increased with stronger speed than the normal population growth rate in Vietnam at present time (Đặng Nguyên Anh 2011; Nguyễn Đình Cử và Nguyễn Đại Đồng 2014; Tổng cục Thống kê và Quỹ dân số liên hợp quốc 2004; Tổ chức lao động quốc tế 2009). Among these forms of migration, the flow from rural to urban area, in long-term and fluctuated forms, is clearly recognized and being happened with stronger levels and degree during the organizational process in Vietnam recently. Among the migrated flows, there is a prominent of rural-urban migration which also led to the existence of social problems in both the depature and destination of the flow. In term of departure of the migration, the lack of workforce occurred in the countryside, and the issue of brain drain also presented, and in other side of destination, there were prominent presentations of urban management, services for migrated workers in aspects of employment, income, housing, lifestyle...

As the significant topic in the daily life, research on migration and its related problems are highly paid attention in social science research in Vietnam recently, from different research approaches in sociology, economics, cultural studies, urban study... Recent research on migrants focused more on the following topics in Vietnam: the policy system on the rural-urban migration (Đặng Nguyên Anh 2011; Nguyễn Đình Cử và Nguyễn Đại Đồng 2014); the role of rural-urban migration to the rural development (Action Aid Việt Nam 2010; Lê Thị Kim Ánh và cộng sự 2011; Trần Xuân Cầu 2007); or the research about social problems, migration management and service models for migrants in the urban areas (Lê Bạch Dương và Nguyễn Thanh Liêm 2011; Đào Thị Ngọc Mai và Nguyễn Thị Ngọc Thanh 2009; Manolo và Geoffrey 2011; Tổ chức Lao động quốc tế và Viện khoa học lao động xã hội 2009). It is clear that recent migration research in Vietnam look at the urban migration and migrants in different perspectives: role of migration to social development, its related social issues, and required social services for migrants. However, there is lack of specific research emphasizing to the social policy 
and inclusion for migrants and also lack of research to identify the social service accessed by the migrants, and how they find difficulties and advantages on such service usage process as well.

This paper focuses on the quantitative analysis on social inclusion of the migrated workers in the two biggest cities in Vietnam of Hanoi and Ho Chi Minh City. The data for this paper is generated from the national research project on the "Theoretical Perspectives on Social Inclusion and Social Inclusion for the poor migrants in urban in the contemporary modernization and industrialization" funded by Nafosted (2003-2015), with aims at the significant dimension of social inclusion for migrants as the social participation in the local community and workplace.In addition, this paper also aims at evaluating the social participation of migrants in the local community activities, their social relations, and life experiences with other migrants and local people based on the social inclusion perspective. By such analysis, the paper recommends and suggests the support models for migrants during the urbanization process in Vietnam.

\section{Theoretical Approach and Research Methods}

This paper is driven from the theoretical perspective of social inclusion which is widely applied in different research topics (IFSW 2012; Trần Văn Kham 2013) in different scopes such as migration, the social support provision for the vulnerable groups and marginalized people, and specific supports for people on the integration process. This perspective is viewed from the interdisciplinary approach in social research currently. Migration is also known as integration process, and the social inclusion perspective is suggested as the research direction and tendency toward the sustainable development of a society, and to have the coverage supports to vulnerable groups in general and to the poor migrant in particular in the societal life.

Social research basing on social inclusion perspectives are popular since the late 1990s in Western social research, while many social issues were not purely and completely dealt with the economic solutions, they required the comprehensive measures which were based not only the economic solutions but also on those ones with cultural and social backgrounds. Social inclusion research is known as the direction for promoting the government role on making the equal society for all and which has enough capacities on solving social issues. Such research direction is applied widely in some welfare states such as Australia, Canada, Sweden where the welfare system is capable to make provision and where the social services are various forms and levels for different purposes. Recent biannual joint social work conferences by International Federation of Social Workers and International Association of School of Social Work (TrầnVăn Kham 2013) also paid more attention to this topic and made it as prominent forum for discussions with attractions from different approaches worldwide. In addition, there areexistence of the debates around the services for vulnerable groups and request to have inclusive research and specific initiatives towards the inclusive society. These recent discussions about the social inclusion and inclusive research aimed at making the social development and society for all regardless the cultural backgrounds and social status.

Social inclusion based research has its long-term history in the world. In the early 1980 s, research projects in Western countries of the UK, France and the US, and other developed countries focused more on social exclusion relating to the poverty, unemployment and political crisis (TrầnVăn Kham 2013). Such direction is increasingly paid attention and being applied in the social sciences with different aspects of economic, culture, and society as well. Then it is replaced with the inclusive and social inclusion perspective. Social inclusion is the main societal purpose in which all members are able to have social participation, to make their voice and their influences. And they have a chance to create the social contribution for development purpose (TrầnVăn Kham 2013). Social inclusion is dual dimension process: each individual is willing to and try to have social participation in society, and in other side of society provides good conditions for all its individuals to participate and join equally and voluntarily. In additions, accessing to the social services in the community and social spheres is an identified indicator for looking at the integration process of individual life in society and with others in their daily experiences.

Table 1. Survey sample.

\begin{tabular}{llll}
\hline & Hanoi & Ho Chi Minh City & Total \\
\hline $\mathrm{N}$ & 644 & 398 & 1042 \\
$\%$ & 61.8 & 38.2 & 100 \\
Gender (\%) & & & \\
Male & 45.7 & 38.8 & 51.4 \\
Female & 54.3 & 61.2 & 48.6 \\
Educational levels (\%) & & & \\
Illiterate & 0.5 & 1.8 & 1.0 \\
Primary & 2.0 & 27.9 & 11.8 \\
Secondary & 16.3 & 47.5 & 28.1 \\
High school & 36.6 & 16.0 & 28.8 \\
College/university & 41.8 & 6.3 & 28.3 \\
Post-graduated & 2.8 & 0.5 & 1.9 \\
Marital status (\%) & & & \\
Never married & 47.3 & 16.0 & 35.8 \\
Married & 51.2 & 77.3 & 60.8 \\
Divorce & 0.6 & 4.8 & 2.2 \\
Widowed & 0.9 & 1.9 & 1.3 \\
Means of age & 30.35 & 36.68 & 32.79 \\
\hline
\end{tabular}

Basing on such ideas and approach, this paper aims at identifying the social service accessed by migrants in their integration process in the urban life, with some specific comparison between the two contexts of the research that is considered as significant factor to the inclusive process of the poor migrants. Such social services are identified with impacts in terms of the general public services, the health care services and some specific social services relating to the daily experiences of the poor migrants. The main 
research question for this paper as how the migrants access to social services in their daily life? Are there any difficulties and restrictions? Are there any impacted factors to their accessing?

In order to make the explanation for such research question, this research applies the data collection methods in forms of document analysis, surveys and individual interviews with migrants in Hanoi and Ho Chi Minh City. The survey sample of the research is presented in the table 1. The research applies the data generation by the software of SPSS version 21.0 for the survey findings for processing the quantitative data and uses the thematic analysis for the interview responses to make the qualitative data and its explanations. This research follows all ethical considerations by the NafostedViệt Nam, with approval project number I3.1-2012.11. Research participants are voluntary without any coercions, all individual information is coded and anonymous.

\section{Research Findings}

\subsection{Number of Friends in the Urban Life}

On looking at the degree of the inclusion by the migrants, the first indicator for such assessment is how many friends the migrant has in their new life. This analysis aims at identifying the social network of migrants in the new urban life contexts. The friendship is viewed in terms of friends from the same home village; friends as the other migrants; and friends in the workplace. The mean value of the friends in such groups is presented in the following table:

Table 2. The mean of friends among migrants.

\begin{tabular}{lllll}
\hline Friends who are & Total & Hanoi & Ho Chi Minh city \\
\hline From the same home village & 5,57 & 5,89 & 4,91 \\
Other migrants & 10,76 & 12,42 & 6,57 \\
Those in the same workplace & 9,07 & 9,02 & 9,17 \\
\hline
\end{tabular}

As described in the table 2, almost friends of the migrant are those in the same condition as the migrant (more than 10 friends) and those in the same workplace (around 9 friends). Responses from migrants are different by the research site, those migrants in Hanoi have the mean of friends from the same home village and as other migrants higher than those from Ho Chi Minh city, and such responses are in opposite direction in the indicator of "friend from the same workplace".

\subsection{Visiting Frequency of Migrants}

Social inclusion by migrants is also approached throughout the frequency of their visits to or from the friends or authorativeorganizations in the urban locality. Indicators for such observation are designed in 4 Likert scales, from 1 as never visited to 4 as frequent visited.

From the mean value in total, it is found that in indicator of visiting others, the more frequency is for those as residential fellows. The following is for those in the same workplace, home village fellows, friends in the city ... it is quite opposite to the visiting to the local authorities or local union representatives which is closed to the meaning of "never". It is the same meaning to the indicator of being visited. In this aspect, people in the same living area visit frequently to the migrants, as the highest mean values among the responses. Those migrants from the same workplace, same home village, closed friends have their visitings closed to frequent and sometime. The visits by the local government staff or local union representatives are less frequent. In brief, the visitings to others by migrants are more active than being visited by the others in almost observed indicators, except for the indicators related to the local government and local union/association representatives.

Table 3. Visiting frequency of migrants (Means1).

\begin{tabular}{|c|c|c|c|c|c|c|}
\hline & \multicolumn{2}{|l|}{ Total } & \multicolumn{2}{|l|}{ Hanoi } & \multicolumn{2}{|c|}{ Hochiminh City } \\
\hline & Visiting & $\begin{array}{l}\text { Being } \\
\text { visited }\end{array}$ & Visiting & $\begin{array}{l}\text { Being } \\
\text { visited }\end{array}$ & Visiting & $\begin{array}{l}\text { Being } \\
\text { visited } \\
\end{array}$ \\
\hline $\begin{array}{l}\text { Relatives in } \\
\text { the city }\end{array}$ & 2,39 & 2.37 & 2.37 & 2,54 & 2,06 & 2.08 \\
\hline $\begin{array}{l}\text { Friends in the } \\
\text { city }\end{array}$ & 2,48 & 2.45 & 2.45 & 2.63 & 2,18 & 2.15 \\
\hline $\begin{array}{l}\text { Home village } \\
\text { fellows }\end{array}$ & 2,49 & 2,48 & 2,48 & 2.66 & 2,19 & 2,18 \\
\hline $\begin{array}{l}\text { Residential } \\
\text { fellows }\end{array}$ & 2,98 & 2.95 & 2.95 & 2.96 & 2.93 & 2.93 \\
\hline $\begin{array}{l}\text { Those in the } \\
\text { same } \\
\text { workplace }\end{array}$ & 2,76 & 2,69 & 2,69 & 2.75 & 2,63 & 2,58 \\
\hline Local people & 2.19 & 2,15 & 2,15 & 2,16 & 2.14 & 2,14 \\
\hline $\begin{array}{l}\text { Local } \\
\text { government } \\
\text { representatives }\end{array}$ & 1,77 & 1,85 & 1,85 & 1,81 & 1,65 & 1,92 \\
\hline $\begin{array}{l}\text { Local union } \\
\text { representatives }\end{array}$ & 1,78 & 1,87 & 1,78 & 1,76 & 1.78 & 2,09 \\
\hline
\end{tabular}

For those migrants in Hanoi, their visiting seems active in compared to the aspect of being visited in all mentioned indicators. While there is not same trend to those in Ho Chi Minh city, with unclear tendency of visiting or being visited. Migrants in Hanoi are more active on visiting, except for the action to the local government and police staff or local union representatives, and it is opposite to those in Ho Chi Minh city who responded actively on visiting to the local government and union staff.

\subsection{Ways on Solving the Life Difficulties}

It is witnessed that the migrants face difficulties in the new life contexts in the urban in terms of economic, social relations, accessing to social services, and enjoying the relax activities as well. On facing such difficulties, how they dealt with and what social network and relations could support them on making the solutions. This research also pointed out

1 The mean value is measured in the 4 Likert scales' questions, from 1 to 4 , equivelant to the meanings of never visited to frequent visited; each value group is calculated in the formula of $(4-1) / 4=0.75$. So, mean value from 1.0 to 1.75 : never; from 1.76 to 2.50 : sometime; from 2.51 to 3.25 : frequent and above 3.25 : very frequent. 
some indicators, asking supports from the relatives to friends or local authorities. These observed indicators are included in the 4 Likert scales, from 1: never asking to 4 : frequently asking for supports.

Table 4. Means of the way to deal with life difficulties (Means2).

\begin{tabular}{llll}
\hline Statements & Total & Hanoi & $\begin{array}{l}\text { Ho Chi } \\
\text { Minh city }\end{array}$ \\
\hline $\begin{array}{l}\text { Try to dealt problems by themselves } \\
\begin{array}{l}\text { Ask supports from relatives in the } \\
\text { home village }\end{array}\end{array}$ & 3.70 & 3.69 & 3.72 \\
$\begin{array}{l}\text { Ask supports from relatives in the } \\
\text { same city }\end{array}$ & 2.20 & 2.55 & 1.93 \\
$\begin{array}{l}\text { Ask supports from other home village } \\
\text { fellows }\end{array}$ & 2.10 & 2.31 & 1.85 \\
$\begin{array}{l}\text { Ask supports from the workmates or } \\
\text { those in the same living area }\end{array}$ & 2.45 & 2.43 & 2.47 \\
$\begin{array}{l}\text { Asking supports from the local people } \\
\text { Asking supports from the local }\end{array}$ & 1.95 & 2.00 & 1.88 \\
$\begin{array}{l}\text { government representatives } \\
\text { Asking supports from the local } \\
\text { organizations }\end{array}$ & 1.76 & 1.77 & 1.76 \\
\begin{tabular}{l} 
Asking supports from others \\
\hline
\end{tabular} & 1.77 & 1.83 & 1.67 \\
\hline
\end{tabular}

The table of mean value shows that the most favorable ways to deal with life difficulties by migrants based on the self-solving, then "ask supports from those in the same living context", "ask supports from the relatives by phone-calls", "ask supports from relatives in the same city:, and the less preferable way is from the local government and union/organization staff. Almost responses for asking supports from local government and union staff are closed to never option.

\subsection{Social Participation in the Local Community/Workplace}

Table 5. Degree of being invited to the local activities (\%).

\begin{tabular}{|c|c|c|c|}
\hline \multirow{2}{*}{ Type of local activities } & \multicolumn{3}{|c|}{ Being invited } \\
\hline & Total & Hanoi & Ho Chi Minh city \\
\hline Attending the street meetings $* * *$ & 53.5 & 27.2 & 96.5 \\
\hline Voting in the local community** & 33.7 & 30.9 & 38.2 \\
\hline $\begin{array}{l}\text { Attending the festival activities in } \\
\text { the community } * * *\end{array}$ & 55.0 & 35.1 & 87.5 \\
\hline $\begin{array}{l}\text { Attending the cultural and sport } \\
\text { activities in the community*** }\end{array}$ & 43.0 & 25.8 & 71.4 \\
\hline $\begin{array}{l}\text { Attending the workplace's } \\
\text { activities *** }\end{array}$ & 50.9 & 44.1 & 62.0 \\
\hline $\begin{array}{l}\text { Participating the charity activities } \\
* * *\end{array}$ & 55.7 & 49.5 & 65.8 \\
\hline $\begin{array}{l}\text { Member of migrated } \\
\text { clubs/groups*** }\end{array}$ & 34.2 & 18.6 & 60.2 \\
\hline $\begin{array}{l}\text { Member of the local organizations } \\
* * *\end{array}$ & 39.1 & 21.6 & 67.9 \\
\hline $\begin{array}{l}\text { Member of home village fellow's } \\
\text { organization } * *\end{array}$ & 27.2 & 30.1 & 22.2 \\
\hline \multicolumn{4}{|c|}{ Chi-square test with $p^{* *}<0,05$, and $p^{* * *}<0,01$} \\
\hline
\end{tabular}

2The mean value is measured in the 4 Likert scales' questions, from 1 to 4 , equivelant to the meanings of never asking for supports to frequently asking for supports; each value group is calculated in the formula of $(4-1) / 4=0.75$. So, mean value from 1.0 to 1.75 : never; from 1.76 to 2.50 : sometime; from 2.51 to 3.25: frequent and above 3.25 : very frequent.
In the other aspect of social inclusion, this paper looks at the degree of social participation of migrants in the local community or workplace. Perspectives on social inclusion look to the evaluation of two ways of inclusion: from the individual to join the life contexts, and from the life context to welcome the individual. So, the active participation by migrants to the local life is a significant factor on analyzing the social inclusion for migrants. The table below shows the degree of invitation receiving by migrants to the local community activities:

From these responses, the most invited activities for migrants in the new urban life contexts are charity, fund raising, and those activities relating to the festival, cultural and sport activities ... Some other activities regarding to the rights of the migrants, such as voting, are not paid attention, just around one third of migrants responded to the fact that they are invited to attend, or there is the same responded rate by migrants on participating to the those activities by a group or an association for/by them.

In almost activities, except for the meetings by the home village fellows, the migrants in Ho Chi Minh city seem to be highly invited to attend than those in Hanoi. It is noticeable that $96.5 \%$ of migrants in Ho Chi Minh city are invited to attend the street meetings. The meanings taken from these findings show that the migrants in Ho Chi Minh city have their favorable conditions to have social inclusion/participation than those in Hanoi. This impacted factor of invitation contributes to great extents of social inclusion for migrants in their urban life. In the other side, this paper identified the aspect of how migrants participate in the local activities in the same 9 observed variables as the above table. These variables based on the 4 Likert scales questions, from the value of 1 as never to 4 as very frequency of participation. The participated degree on social activities and organization presented as the following mean table:

Table 6. Participation in local activities and organization by migrants (means).

\begin{tabular}{|c|c|c|c|}
\hline Means3 & Total & Hanoi & $\begin{array}{l}\text { Ho Chi } \\
\text { Minh city }\end{array}$ \\
\hline Attending the street meetings & 2,50 & 2,37 & 2,71 \\
\hline Voting in the local community & 2,09 & 2,32 & 1,65 \\
\hline $\begin{array}{l}\text { Attending the festival activities in the } \\
\text { community }\end{array}$ & 2,50 & 2,54 & 2,40 \\
\hline $\begin{array}{l}\text { Attuning the cultural and sport } \\
\text { activities in the community }\end{array}$ & 2,41 & 2,52 & 2,19 \\
\hline Attending the workplace's activities & 2,36 & 2,45 & 2,21 \\
\hline Participating the charity activities & 2,52 & 2,69 & 2,21 \\
\hline Member of migrated clubs/groups & 2,13 & 2,22 & 1,94 \\
\hline Member of the local organizations & 2,16 & 2,23 & 2,04 \\
\hline $\begin{array}{l}\text { Member of home village fellow's } \\
\text { organization }\end{array}$ & 1,93 & 2,27 & 2,16 \\
\hline
\end{tabular}

3 The mean value is measured in the 4 Likert scales' questions, from 1 to 4 , equivelant to the meanings of never asking for supports to frequently asking for supports; each value group is calculated in the formula of (4-1) $/ 4=0.75$. So, mean value from 1.0 to 1.75 : never; from 1.76 to 2.50 : sometime; from 2.51 to 3.25: frequent and above 3.25 : very frequently. 
As the same value from being invited to the local activities/organization, migrants actively participate in charity, fundraising and street meetings (closed to frequency); while the other activities which migrants hardly attend such as participation in local organizations, and in home village fellow meetings in the urban.

The mean table also showsthe different responses among the research locations between Hanoi and Ho Chi Minh city. Migrants in Hanoi tend to actively attend in almost activities in compared to those in Ho Chi Minh city, except for the street meetings. In term of being invited to social participation, from the above tables of 5 and 6 , it is found that migrants in Ho Chi Minh city have the good life conditions, however the frequent degree of their social participation in the locality is lower than those in Hanoi, except for the street meetings.

\subsection{Free Time Social Activities}

Life experiences in the local life in different behavior models are identified to make the social construction of the migrants. Their participation in the local and relax activities is regarded as analyzed factors in this research. There are 12 observed variables for free time activities by migrants. As the same designed of the research questions, these variables are 4 Likert scale format, from the scale 1 as never participation to the scale 4 as very frequent participation. The value ofCronbach's Alpha amongthese12 variables is 0.784, it means that these variables are well-designed in the research of social inclusion for the migrants and compatible for further statistical analyzing and testing.

Table 7. Frequency of participation to free time activities among migrants (means).

\begin{tabular}{llll}
\hline & Total & Hanoi & Ho Chi Minh city \\
\hline Chatting with friends & 2.87 & 3.09 & 2.53 \\
Sleeping/relaxing & 3.61 & 3.62 & 3.61 \\
Searching internet & 1.56 & 1.80 & 1.16 \\
Cooking and drinking with friends & 2.22 & 2.41 & 1.92 \\
Visiting friends/relatives & 2.63 & 2.77 & 2.41 \\
Readings & 2.60 & 2.72 & 2.41 \\
Going to church/pagoda & 2.20 & 2.35 & 1.94 \\
Street hang-around & 3.25 & 3.11 & 3.48 \\
Watching TV & 3.25 & 3.11 & 3.48 \\
Go shopping & 2.49 & 2.58 & 2.32 \\
Back home villages & 2.80 & 2.95 & 2.57 \\
Going to cafe & 2.03 & 2.14 & 1.85 \\
\hline
\end{tabular}

Note: the higher mean is, the more frequent participating is.

Implications from the table show that the frequent activities by migrants in the free time are sleeping, relaxing and watching television. The less frequent activities are going back home village, visiting friends, chatting with friends, readings or go shopping. Some other activities in terms of cooking, drinking, street hanging around are done by migrants at degree of "sometimes". The lowest degree of participation in the free time is searching internet in the public internet corners with mean value at 1.56 (nearly never). So, in compared to the more frequent activities by the local people, the migrants seem less participated. These responses also show the individualized and closed characteristics among migrants in their peer groups. They also exposed the implications of the limited income, the poor conditions in the cultural life, and the less livelihood among the migrants in the contemporary urban life in Vietnam..

\subsection{Life Experiences Among the Social Problems}

Besides the identification of social inclusion through the social participation in the local life, this research also looked at the life experiences by migrants in the urban social problems. These problems are developed in 12 observable variables relating to daily experiences by migrants. These variables are calculated in 4 Likert scales, from 1 as never and 4 as very frequent. The Cronbach's Alpha among these variables is 0.885 which shows that these variables are welldesigned and compatible in the whole research of inclusion for migrants.

Table 8. Life experiences of migrants to the social problems (means).

\begin{tabular}{llll}
\hline Social problems & Total & Hanoi & $\begin{array}{l}\text { Ho Chi } \\
\text { Minh city }\end{array}$ \\
\hline Hard to find a job & 2.64 & 2.85 & 2.31 \\
Competition to employment finding & 2.39 & 2.70 & 1.88 \\
$\begin{array}{l}\text { Lack of working skills and } \\
\text { experiences }\end{array}$ & 2.29 & 2.53 & 1.89 \\
Heavy and dangerous jobs & 1.99 & 2.18 & 1.68 \\
$\begin{array}{l}\text { Being negative attitude by the } \\
\text { employers }\end{array}$ & 1.67 & 1.80 & 1.46 \\
$\begin{array}{l}\text { Being sexual abused } \\
\text { Being isolated by the local people }\end{array}$ & 1.22 & 1.33 & 1.05 \\
$\begin{array}{l}\text { Being looked-down by the local } \\
\text { government/police staff }\end{array}$ & 1.32 & 1.40 & 1.14 \\
Being threatened & 1.37 & 1.50 & 1.07 \\
Being discrimination & 1.41 & 1.50 & 1.25 \\
$\begin{array}{l}\text { Stress in the spouse relationship } \\
\text { Stress on money earnings }\end{array}$ & 1.84 & 1.74 & 2.00 \\
\hline
\end{tabular}

From the table of mean value, the most experienced problem among the migrants is "hard to find a job", "competition to employment findings", "stress on money earning for family" and "lack of working skills and experiences". The migrants face other problems at the less frequency at sometimes or never degree. It is found that the migrants do not meet any problems of being discriminated or threatened, isolated as they are living in their own contexts, lack of opened contacts and less paid attention to local community activities. Almost severe problems in which the migrants face related to the individual life rather than the community and contextual problems

In comparison between two research sites, the mean value shows that migrants in Hanoi face more difficulties on job finding, employment competition, and lack of working experiences and skills as well. In additions, the migrants in Hanoi also face challenges in the other problems of being abused, being discriminated, being threatened. This situation led to the implications that the migrants in Hanoi face 
difficulties in not only the individual problems but also in the contextual and living conditions in the new urban life.

Based on the value of Cronbach's Alpha among the observable variables, the research applies the exploratory factor analysis (EFA). By such analyzing, the KMO value is 0.906, and the meaning of the Barllett value of $\mathrm{p}$ is 0.0000 , which shows that these variables are closely related.

Table 9. EFA on the life experiences by migrants in social problems.

\begin{tabular}{llll}
\hline & Group 1 & Group 2 & Group 3 \\
\hline $\begin{array}{l}\text { Being isolated by the local people } \\
\text { Being looked-down by the local }\end{array}$ & 0.856 & & \\
government/police staff & 0.848 & & \\
Being threatened & 0.808 & & \\
Being sexual abused & 0.802 & & \\
Being discrimination & 0.772 & & \\
Being negative attitude by the & 0.509 & & \\
employers & & & \\
Hard to find a job & & 0.843 & \\
Competition to employment finding & & 0.843 & \\
Lack of working skills and & & 0.807 & \\
experiences & & 0.630 & \\
Heavy and dangerous jobs & & & \\
Stress in the spouse relationship & & & \\
Stress on money earnings & & & \\
Means(total) & 1.42 & 2.33 & 2.08 \\
Means (Hanoi) & 1.54 & 2.57 & 0.600 \\
Means (Ho Chi Minh city) & 1.23 & 1.94 & \\
Cronbach's Alpha & 0.900 & 0.841 & \\
KMO & 0.906 & & \\
Barlett's significant & 0.000 & & \\
Average Variance Extracted & $71.13 \%$ & & \\
\hline & & & \\
\hline
\end{tabular}

As the average variance extracted at $71.9 \%$, from the EFA, all 12 variables have their own factors higher than 0.5 , in which show that these variables are grouped into three compatible groups as described in table 9. The first group covers the problems from contexts, the second one includes those problems in term of employment, and the last one relates to the family issues. The Cronbach's Alpha of each group is compatible for the follow-up analysis.

The mean value of each group also shows that the first group has the value at closed to never experience to such problem in the group, while the value of group 3 is around the meaning of sometime, and the value of group 2 is at frequent experience to the identified problems. The mean value is also different among migrants in Hanoi and Ho Chi Minh city. Those migrants in Hanoi experience problem with higher degree than those in Ho Chi Minh city, especially those individual problems. Such evaluation is closely related together between the living place and social problems as the significant value of these 12 variables from the Chi-square testing of $\mathrm{p} 0,000<0,05$.

\section{Conclusions}

Among the assessment and evaluation on the participation the the local activities by migrants, the findings from 6 areas: number of friends, visiting frequency, ways on dealing with life problems, social participation in local activities, free time activities in the local life, and life experiences to social problems, led to the following implications

In almost aspects of analysis, the migrants in the urban seem spend their time and efforts for their livelihood, so their life in the new context seems to be isolated and separated from the local life. Their social relationship and network, and social activities are limited in the small groups or with other migrants only. It also means that their closed contacts the other migrants who have the same conditions, same home village, co-workers in the workplace and home mates in the living areas.

The degree of participation to social organization in the local life and workplace by migrants are clearly presented to some areas directly related to the migrant life. The migrant is not active on such participation with the local people and organizations. In some activities which are invited by the local people and local government staff, their social participation seem to be more open and more active. It means that the migrants are not aware of their role in the local life during their migration, and do not considered the new urban life is a significant resource for their life on dealing with the difficulties in their inclusion to the new living contexts.

The local people and local government representatives do not pay attention to the migrants and their rights, responsibilities and obligations in the local community. They still neglect the migrants in the motivation to the local activities and in the supports for the migrants. They pay more attentions to migrants while there is a need to have the migrant's contribution through the charity, fundraising or relations to the residential registration for security purpose. So, the visiting and attentions to the migrants are the significant solutions for removing the limitation and barriers between the migrants and local people to make the good condition and contextual for the social inclusion of the migrants.

The cultural life and relaxation among migrants in both Hanoi and Ho Chi Minh city is poor. Almost activities preferred by the local people in aspects of festival, cultural or sport activities are less considered or unknown by the migrants. The tendency of individualizing the relax activities in the free time seem to be popular among the poor migrants in the urban life.

In the living and working places, the social trust of the migrants is so limited. The most trusted belief is for the relatives, other migrants from the home villages, the migrants seem to be suspected to all, and less asking for supports from the neighbor, especially from the staff of local government and organizations.

In spite of having the similarity between the research sites, however, there are differences on culture, life style, and geographic conditions, the social inclusion by migrants in Hanoi and Ho Chi Minh city have their own forms. In some aspects, the migrants in Ho Chi Minh city show their social inclusion at higher degree to those in Hanoi. It also shows that the contextual condition in Ho Chi Minh city is more favorable than that in Hanoi. 
In terms of support models for migrant during the urbanization in Vietnam, it is suggested to pay attention to the social participation in local activities by migrant besides the other supports in terms of economic, employment and trainings. It is also required to have further support and involvement by the local government, organization and union to make the conditions for migrants to be socially included in the local life. In addition, it is needed to make any necessary conditions for migrants to be actively participated in local community, and help them to make the local life as significant resources to deal with any difficulties in the daily experiences; and to upgrade their social trusts to the new living contexts.

\section{Acknowledgement}

This paper is one part of the national research project on the "Theoretical Perspectives on Social Inclusion and Social Inclusion for the poor migrants in urban in the contemporary modernization and industrialization" funded by Nafosted, Vietnam no.I3.1-2012.11.

\section{References}

[1] Action Aid Việt Nam, Oxfam Anh and Oxfam Hồng Kông (2010). Theo dõi nghèo đô thị theo phương pháp tham gia/Observing the urban poverty from the participation methods. Action Aid, Hanoi.

[2] Đặng Nguyên Anh and nhóm nghiên cứu Trung tâm VAPEC Hà Nội (2011). Nghiên cứu tác động phát triển của di cư quốc tế tại Việt Nam/Researching the developmental impacts by international migration in Vietnam, Viện Khoa học xã hội Việt Nam, Hanoi.

[3] Lê Thị Kim Ánh, Phạm Thị Lan Liên, Nguyễn Tuấn Hưng (2011). Người lao động di cư đến các khu công nghiệp điều kiện sống, sinh hoạt và tình hình sử dụng dịch vụ $\mathrm{y}$ tế/Migrants in the industrial parks: living conditions and the current situation of using healthcare services. Tạp chí Y tế thực hành/Journal of Medical Practices (764), số 5/2011, $\operatorname{tr} 154-158$.

[4] Trần Xuân Cầu. (2007). Sức ép của lao động nhập cư trong các khu công nghiệp và chính sách đối với họ/The pressures of migrated labours in the industrial parks and social policies for them, Tạp chí Kinh tế và Phát triể/Journal of Economics and Development, Đại học Kinh tế quốc dân/National Economic University.
[5] Nguyễn Đình Cử and Nguyễn Đai Đồng. (2014). Di cư nông thôn-đô thị ở Việt Nam:Đôi điều bàn lại/Rural-Urban migration in Vietnam: Implications need reviewing, Khoa Thống kê, Trường Đại học Kinh tế quốc dân, retrieved on 26/3/2015, tại $<$ http://www.khoathongke.neu.edu.vn/ViewNCKH.aspx?ID=43>.

[6] Lê Bạch Dương and Nguyễn Thanh Liêm. (2011). Từ nông thôn ra thành phố: Tác động kinh tế - xã hội của di cư ở Việt Nam/From rural to urbans: social and economic impacts of migration in Vietnam, Viện Kinh tế phát triển xã hội/Institute of Social and Economic Development, Hanoi.

[7] IFSW. (2012). World Joint Conference on Social Work and Development, Stockholm, Sweden.

[8] Đào Thị Ngọc Mai and Nguyễn Thị Ngọc Thanh. (2009). "Dịch vụ xã hội đối với nhóm lao động di cư/Social Services for Migrated Labourers, Viện kinh tế Việt Nam/Institute of Vietnamese Economics, Hanoi.

[9] ManoloI. Abella and Geoffrey M. Ducanes. (2011). Báo cáo Triển vọng kinh tế Việt Nam và hàm ý đối với chính sách di dân/Report on the Prospect of Vietnam Economics and Implications for Migrated Social Policies, Ministry of Labors, Invalids and Social Affairs, Hanoi.

[10] Tổ chức lao động quốc tế and Viện Khoa học lao động xã hội (2009). Báo cáo kêt quả nghiên cứu của đề tài: "Thực trạng tuyển dụng và việc làm của lao động nữ di cư tới các khu công nghiệp, khu chế xuất tại Việt Nam"/Report on the current situation of employment recruitment and jobs for female migrated workers in the industrial parks and zones in Vietnam, Ministry of Labors, Invalids and Social Affairs, Hanoi.

[11] Tổng cục thống kê and Quỹ dân số Liên hợp quốc (2004). Di cư trong nước và mối liên hệ với các sự kiện của cuộc sống/Domestic migration and its links to the life events, Report on National Census's Findings, Hanoi.

[12] Tổng cục thống kê (2011). Di cư và đô thị hóa ở Việt Nam: thực trạng, $\mathrm{xu}$ hướng và khác biệt/Migration and industrialisation in Vietnam: current situation, trend and difference, GSO Publishing House, Hanoi.

[13] Trần Văn Kham (2013). Nghiên cứu về hoà nhập xã hội: Một số hàm ý cho Việt Nam/Researching on Social Inclusion: Implication for Social Research in Vietnam, Tạp chí Khoa học/Journal of Social Sciences, Vietnam National UniversityHanoi, Vol 24, no,4, pp.236-246.

[14] UNDP.(2013). Đánh giá nghèo đô thị ở Hà Nội và thành phố Hồ Chí Minh/Assessing the urban poverty in Hanoi and Ho Chi Minh city, UNDP, Hanoi.

[15] UNFPA (2011). Báo cáo tình trạng dân số thế giới năm 2011/World Population Report in 2011, UNFPA in Hanoi, Hanoi. 